Research Article

\title{
A study of factors influencing nutritional status of under five children in a tertiary teaching hospital
}

\author{
Manjunath M., Mallikarjun K. Biradar*, Nagaraj Goud B., Jahnavi Rajagopal
}

Department of Community Medicine, MIMS, Mandya, Karnataka, India

Received: 09 December 2015

Accepted: 08 January 2016

*Correspondence:

Dr. Mallikarjun K. Biradar,

E-mail: mallubiradar82@gmail.com

Copyright: (C) the author(s), publisher and licensee Medip Academy. This is an open-access article distributed under the terms of the Creative Commons Attribution Non-Commercial License, which permits unrestricted non-commercial use, distribution, and reproduction in any medium, provided the original work is properly cited.

\begin{abstract}
Background: Nutrition is a core pillar of human development, influences growth and development before as well as after birth, around $90 \%$ of the world undernourished children live in Asia and Africa. In India among under-five children $43 \%$ are underweight and $20 \%$ have wasting due to acute under-nutrition. The study was conducted to assess socio demographic characteristics of the family and to assess nutritional status of children attending under five clinics. Methods: Retrospective record based data was obtained from the register of under-five clinic, MIMS, Mandya from the mothers who attended under five clinics from September 2012 - August 2013 (1 year).

Results: A total of 8506 children attended under-five clinic in the study period. $68.0 \%$ of mothers were in the $20-25$ years age group. $82 \%$ of mothers had education above secondary school level, while $6.2 \%$ of mothers are illiterate. Majority of the families $(88.4 \%)$ belongs to lower socio economic class and $67.9 \%$ were living in joint family. Malnutrition in the form of overweight and underweight has been observed in 2517 (74.0\%) children, who were class IV SES, followed by $640(18.8 \%)$ in class V.

Conclusions: Majority of the children attending under five clinics belongs to joint family and low socio economic status. A significant of them were malnourished have been observed in lower socio economic people.
\end{abstract}

Keywords: Nutritional status, Under-five children, Overweight, Underweight

\section{INTRODUCTION}

Good nutrition early in a life is a key input for human capital formation, a fundamental factor for sustainable and equitable economic growth. Any major deviation in the nutrient intake either in quality or in quantity from its requirement can affect growth in many ways. ${ }^{1}$ Nutrition is a core pillar of human development, and the level of child under-nutrition remains unacceptable throughout the world, with $90 \%$ of the developing world's chronically undernourished children living in Asia and Africa. In India $43 \%$ of children under five years are underweight, $20 \%$ of children under five years of age suffer from wasting due to acute under-nutrition. More than one third of the world's children who are wasted live in India. ${ }^{2}$ Normal growth and development take place only if there is optimal nutrition. Nutrition influences growth and development before as well as after birth. Retardation of growth rate is an indication of malnutrition. Measurement of weight and rate of gain in weight are the best single parameters for assessing physical growth. This is best done on growth chart. ${ }^{3}$ Various maternal factors which influence nutritional status of under five children which includes, age at marriage, child bearing, child spacing, family size patterns, level of education, economic status, customs and beliefs. ${ }^{4}$ Freedom from hunger and malnutrition is a basic human right and their alleviation is a fundamental prerequisite for human and national development. ${ }^{5}$ An estimated $54 \%$ of all childhood deaths occurs globally because of malnutriton. ${ }^{6}$

There are only few studies available regarding the factors influencing the nutritional status of under five children, 
hence the proposed study seeks information regarding the nutritional status of under five children attending under five clinic and also to assess nutritional status of children attending under five clinic.

\section{METHODS}

It is a retrospective record based study. The data for the purpose of the study was obtained from the registers of under-five clinic, Mandya Institute of Medical Sciences, Mandya with permission. After obtaining the permission and clearance from the Institutional Scientific committee and ethical committee, the data on nutritional status of children which has been recorded during the visit has been obtained and also the socio economic characteristic of the mother such as, age of mother, education of mother, SES and type of family are obtained from the register of the under-five clinic during the study period from September 2012 to August 2013. Children whose data were incomplete and out of study period were excluded. The data was entered and analysed using Microsoft excel software. Descriptive statistics were used to analyse the data.

\section{RESULTS}

Table 1: Socio-demographic characteristics of the family.

\begin{tabular}{|lll|}
\hline Indicators & Number $(\mathbf{n = 8 5 0 6})$ & Percentage $(\%)$ \\
\hline Age & & \\
\hline$<20$ & 460 & 5.4 \\
\hline $20-25$ & 5784 & 68.0 \\
\hline $26-30$ & 1796 & 21.1 \\
\hline $31-35$ & 408 & 4.8 \\
\hline$>36$ & 58 & 0.7 \\
\hline Mothers education & \\
\hline Illiterate & 527 & 6.2 \\
\hline Primary & 1003 & 11.8 \\
\hline Secondary & 3572 & 42.0 \\
\hline PUC & 1983 & 23.3 \\
\hline $\begin{array}{l}\text { Graduation } \\
\text { \& above }\end{array}$ & 1421 & 16.7 \\
\hline Socio economic status & \\
\hline Class I & 153 & 1.8 \\
\hline Class II & 834 & 9.8 \\
\hline Class III & 2892 & 34.0 \\
\hline Class IV & 3572 & 42.0 \\
\hline Class V & 1055 & 12.4 \\
\hline Type of family & \\
\hline Nuclear & 2730 & 32.1 \\
\hline Joint & 5776 & 67.9 \\
\hline Total & 8506 & 100 \\
\hline
\end{tabular}

In the present study, 8506 mothers attended under five clinics. $68.0 \%$ of mothers were in the 20-25 years age group. $82 \%$ of mothers had education above secondary school level, while $6.2 \%$ of mothers are illiterate.
Majority of the families $(88.4 \%)$ belongs to lower socio economic class and $67.9 \%$ were living in joint family (Table 1).

Table 2: Distribution of study subjects based on nutritional status.

\begin{tabular}{|llc|}
\hline Malnutrition status & Number & Percentage \\
\hline Normal & 5103 & $60.0 \%$ \\
\hline Underweight & 2951 & $34.7 \%$ \\
\hline Overweight & 452 & $5.3 \%$ \\
\hline Total & 8506 & 100 \\
\hline
\end{tabular}

Out of the total 8506 children, we found out that 2951 $(34.7 \%)$ were found to be suffering from underweight and $451(5.3 \%)$ from overweight. Children in the normal nutritional status were found to be $5103(60 \%)$ (Table 2).

Table 3: Gender wise distribution of children according to degree of malnutrition.

\begin{tabular}{|llll|}
\hline Malnutrition status & Male & Female & Total \\
\hline Normal & 2965 & 2138 & $5103(60.0 \%)$ \\
\hline Underweight & 1207 & 1744 & $2951(34.7 \%)$ \\
\hline Overweight & 268 & 183 & $452(5.3 \%)$ \\
\hline Total & 4823 & 3683 & $8506(100 \%)$ \\
\hline
\end{tabular}

1475 (30.6\%) male children and 1927 (52.3\%) female children were suffering from malnutrition in the form of underweight and overweight (Table 3).

Table 4: Distribution of children according to social class and malnutrition.

\begin{tabular}{|c|c|c|c|}
\hline $\begin{array}{l}\text { Social } \\
\text { class }\end{array}$ & $\begin{array}{l}\text { Normal } \\
\text { children }\end{array}$ & $\begin{array}{l}\text { Malnutrition } \\
\text { (Overweight } \\
\text { and } \\
\text { underweight) }\end{array}$ & Total \\
\hline I & $145(2.8 \%)$ & $08(0.2 \%)$ & $153(1.8 \%)$ \\
\hline II & $831(16.2 \%)$ & $03(0.01 \%)$ & $834(9.8 \%)$ \\
\hline III & $2657(52.0 \%)$ & $235(6.9 \%)$ & $2892(34.0 \%)$ \\
\hline IV & $1055(20.8 \%)$ & $2517(74.0 \%)$ & $3572(42.0 \%)$ \\
\hline V & $415(8.2 \%)$ & $640(18.8 \%)$ & $1055(12.4 \%)$ \\
\hline Total & $5103(100 \%)$ & $3403(100 \%)$ & $8506(100 \%)$ \\
\hline
\end{tabular}

Malnutrition in the form of overweight and underweight has been observed in $2517(74.0 \%)$ children, who were class IV SES, followed by 640 (18.8\%) in class V. Only $11(0.3 \%)$ of children who were found to be malnourished were in class I \& II (Table 4).

\section{DISCUSSION}

In our study, $40.0 \%$ children were suffering from malnutrition (underweight and overweight). $52.3 \%$ female children were suffering from malnutrition compared to $30.6 \%$ male, which implicate that still there is a lot of negligence in the community regarding 
upbringing of female child. Malnutrition has also been observed in the low socio economic people.

Contrast to our findings, study conducted by Stalin P, et al have shown prevalence of underweight was $52.9 \%$. Around $7 \%$ of children were severely malnourished. In their study higher rate of malnutrition is observed in females $(62.6 \%)$. Children belonging to higher socioeconomic status $(40.0 \%)$ were less malnourished than lower socioeconomic status $(47.2 \%){ }^{7}$ Study by Shreyaswi SM et al have observed $63.16 \%$ malnourished children. ${ }^{8}$ Dhakal MM et al study, mentioned that the burden of malnourishment still haunts the poor with $82.75 \%$ children from low income group i.e. IV \& V by Prasad Scale?.

Study conducted by Saxena N et al found that grade II and III PEM were higher among children of social class V., whereas Patwari AK, study showed that delayed weaning after one year of age, was associated with malnutrition in $53.4 \%$ of children in his study. ${ }^{10,11} \mathrm{~A}$ study conducted in urban slum of Delhi, it was found that there was significant difference among male and female with respect to malnutrition with more females $(9.6 \%)$ suffering from severe malnutrition as compared to male $(6.5 \%)^{12}$

\section{CONCLUSION}

The causes of under nutrition in under-five children are complex and involve multiple factors. Emphasis should be given on maternal nutrition and their education, and improvement of socio-economic status to reduce the burden of childhood under nutrition. Area-specific programmes are to be planned to create an enabling environment for comprehensive nutrition and health education to mothers or care-givers. The present study may also help the policy planners to develop strategies to combat different forms of malnutrition by targeting the high-risk groups.

\section{ACKNOWLEDGEMENTS}

Authors would like to thank all the participants of study. The authors are also grateful to authors, editors and publishers of all those articles, journals and books from where the literature for this article has been reviewed and discussed.

\section{Funding: No funding sources}

Conflict of interest: None declared

Ethical approval: The study was approved by the Institutional Ethics Committee

\section{REFERENCES}

1. Mishra BK, Mishra S. Nutritional anthropometry \& preschool child feeding practices in working mothers of Central Orissa. Stud Home Comm Sci. 2007;1:139-44.

2. UNICEF. Nutrition. Available from: (http://www.unicef.org/india/nutrition.html) accessed on $23^{\text {rd }}$ November 2015.

3. Park K. Textbook of Preventive and Social Medicine. 22 ${ }^{\text {nd }}$ ed. Jabalpur:M/s Banarsidas Bhanot Publishers; 2013.p. 500-2.

4. Kumar D, Goel NK, Poonam C, Mittal, Misra P. Influence of Infant-feeding Practices on Nutritional Status of Under-five Children. Indian Journal of Pediatrics. 2006;73:417-21.

5. WHO EMRO: Nutrition for health and development. www. who.int/nutrition/nhd/en/index. Accessed on November 282015.

6. Arnold F, Choe MK, Roy TK. Son preference, the family-building process and child mortality in India. Population Study. 1998;52:302-15.

7. Stalin P, Bazroy J, Dimri D, Singh Z, Senthilvel V, Sathyanarayanan S. Prevalence of Underweight and its Risk Factors among Under Five Children in a Rural Area of Kancheepuram District in Tamil Nadu, India. IOSR Journal of Dental and Medical Sciences. 2013;3:71-4.

8. Shreyaswi, Sathyanath M, Rashmi, Udayakiran N. Prevalence and risk factors of under nutrition among under five children in a rural community. Nitte University Journal of Health Science. 2013;3:82-6.

9. Dhakal MM, Rai A, Singh CM and Mohapatra SC. Health impact assessment: a futuristic approach in under-five care. Indian Journal of Preventive and Social Medicine 2005;36(3\&4):114-20.

10. Saxena N, Nayer D, Kapil U. Prevalence of Underweight, Stunting and Wasting. Indian Pediatrics. 1997;34:627-31.

11. Patwari AK. Diarrhoea and malnutrition interaction. Indian Journal of Pediatrics. 1999;66(Supp 1):S12434.

12. Kapur D, Sharma S, Agarawal N. Dietery intake and growth pattern of children $9-36$ month of age in an urban slum in Delhi. Indian Pediatrics. 2005;42(4):351-6.

Cite this article as: Manjunath M, Biradar MK, Goud NB, Rajagopal J. A study of factors influencing nutritional status of under five children in a tertiary teaching hospital. Int J Community Med Public Health 2016;3:473-5. 